\title{
高齢者福祉施設における温熱環境と利用者の心理反応に関する研究 MEASUREMENT OF THERMAL ENVIRONMENT AND MENTAL REACTION OF ELDERLY PEOPLE IN WELFARE FACILITIES
}

\author{
姜燕，龍 有二**，香川治 美*** \\ Yan JIANG, Yuji RYU and Harumi KAGAWA
}

\begin{abstract}
The purpose of this study is to clarify the psychological influence of thermal environment on elderly people in their welfares facilities. Two facilities where the elderly people actually used were regarded as objects to conduct the thermo-humidity measurement and hearing survey.

As for actual living environment during investigation time, the range of measured temperature was wider than criteria value of indoor temperature for elderly people in winter and summer. While the range of measured PMV was wider than the standard comfortable value of PMV $(-0.5 \sim 0.5)$ in winter and summer, the elderly people announced that it was neutral for them. Humidity-reaction of elderly people was also duller, and it was also difficult for them to perceive the temperature gradient from head to foot.
\end{abstract}

\section{Keywords : Elderly People, Mental Reaction, Thermal Environment, Thermal Comfort, Hearing Investigation 高齢者, 心理反応，温熱噮境，温冷感，ヒアリング調查}

1. はじめに

高齢社会の到来とともに高齢者用居住施設・通所施設を利用する 高齢者が增えている。利用者が快適で健康に生活する必要条件の一 つとしては、適切な温熱環境が挙げられ、これまでにも、高龄者の 温熱環境に関して、各種施設での実測調査やアンケート調査が実施 され、室内温熱環境の実態や利用者の身体健康評価などが行われて いる。

医学、生理感覚の立場からは、高齢者の皮膚温が若齢者より低く、 感受性が鈍い、皮膚表面水分が減少しているなどの報告がある。例 えば、入来・浅木らは高齢者の体温調節反応及び体温調節機能の効 率について検討し、高齢者の自律性及び行動性体温調節機能、温度 感受器の機能が低下していると報告した ${ }^{1)}$ 。内田・田村らは、女性

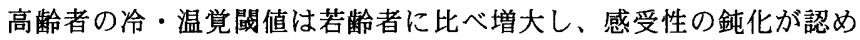
られること、特に後期高齢者の場合に若齢者との差が大きいことを 明らかにしている ${ }^{2)}$ 。

また、高齢者の室内温熱環境に対する温冷感を対象にした実験室 実験も散見され、高齢者と若齢者における温冷感の差を認めている 結果もあれば、両者に明確な差がないと結論づける研究もあった。 前者として、都築は 60 歳以上の健康な高齢者と若齢者を対象として 実験を行い、若龄者に比べて高齢者は冬季では温感受性、夏季は冷 感受性が低下していることを明らかにした ${ }^{3)}$ 。川島らは高龄者と若 齢者の体温調節特性を検討し、温冷感（特に寒さに対する）申告の 幅は若齢者に比べ、狭くなっていることを確認した ${ }^{4)}$ 。後者として は、例えば、衣笠、久保らは高齢者の至適温度範囲を明らかにする
ことを目的として実験を行い、室温に対する快適感と温冷感は高齢

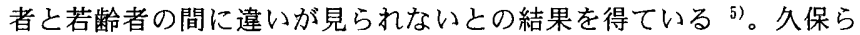
は高秢者男女、若齢者(女子大学生)を対象に人工気候室において快 適感に関する気温調節の実験を行い、両者が選択する温度に明確な 差がないことを報告している ${ }^{6}$ 。また、国外においても、FANGER は 若齢者と高齢者を対象に人工気候室内において快適な温度条件を求 めるという実験的研究により、高齢者の快適温度は若齢者のそれと 異ならないという結果を示した 7)。以上のように、高齢者の室内温 熱環境と心理に関する研究にはまだ不明確な部分が残されている。

高齢者の住宅や高齢者福祉施設の温熱環境に関する研究では、宮 沢、五十嵐らによる国内 6 地区における高齢者を対象にした聞き取 り調査と皮膚温実測調查が特筆され、高齢者の温熱環境の実態につ いて考察している。この研究の結果として、加㱓にともなう感覚評 価能力の鈍化が認められること、そして、冬季の場合に顕著である ことを明らかにしている ${ }^{8)}$ 。また、依田、福田らは北九州市内の福 祉施設を利用した高齢者を対象とし、実測調查とアンケート調查を 行い、空調の使用意識や涼房（通風・除湿）に対する行動について 主に報告している9 。

本調査では、高秢者が害際に生活している施設のうち、通所型福 祉施設を対象に、その利用空間の温熱環境が高齢者の心理反応に与 える影響を明らかにすることを目的とした。なお、高齢者回答の信 頼性担保のため、健康診断等を行った上で、コミュニケーションを 取りながら、温熱環境実測とヒアリング調査を行った。

\footnotetext{
$*$ 北九州市立大学国際環境工学研究科

博士後期課程 · 修士 (工学)

***北九州市立大学国際環境工学部 教授・工博

****北九州市立大学国際環境工学部 研究員・博士 (工学)

Ph. D. Candidate, Faculty of Environmental Engineering, The University of Kitakyushu

Prof., Faculty of Environmental Engineering, The University of Kitakyushu Researcher, Faculty of Environmental Engineering, The University of Kitakyushu
} 


\section{2. 調查内容}

\section{1 調査施設の概要と調査方法}

調查対象施設は通所介護リハビリテーション（以下デイケア） と通所介護(以下デイサービス)である。調査施設の概要を表 1 に 示す。写真 1 は施設の外観であり、雨施設とも 1 階建てである。 写真 2 は夏季調查時の状況である。午前（9 時 30 分〜 11 時）と午 後（昼食後：12 時 30 分〜13 時）に、高捡者に対するヒアリング 調査と室内温熱環境に関する実測調査を並行して実施した。表 2 に両施設のスケジュールを示す。なお、高齢者の生理、心理状態 を安静にするため、調査前に調查員は高齢者と 10 分程度談話した 後、ヒアリング調查を行った。高齢者の回答は調査員（年齢は 20 〜30 代の健康な男女）が記入した。

\section{2 調查対象と調查項目}

表3に調查期間と調査当日の天候、ならびに調查対象者の基本情報 を示す。冬季調査では2施設あわせて高粭者 41 人（男 12 人と女 31 人、

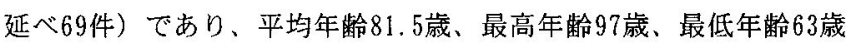
であった。一方、夏季では高齢者のサンプル数は78人（男17人と女 61 人、延べ156件）であり、平均年粭は81藏、最高年齢95墄、最低年 歯63歳であった。各調查期間において、大部分の高齢者は午前と午 後各 1 回ヒアリングを受けるが、冬季 4 人、夏季 3 人の高齢者は重複 して2回のヒアリングを受けている。図1に高齢者の年齢のヒストグ ラムを示す。調查対象の年齢は非常に幅が広い。本研究の被験者は 前期から後期までの高歯者（主に後期高齢者）を対象としている。 なお、高龄者が施設に到着した後、健康診断を行い、職員が健康で あると確認した高齢者を調査対象とした。

表4に実測及びヒアリング調査項目を示す。物理環境要素（温熱環 境）の実測については、ヒアリング調査時間帯のみ各施設の調査位 置 (活動室兼食堂)において床上から $10 \mathrm{~cm} 、 60 \mathrm{~cm}$ と $150 \mathrm{~cm}$ に小型温湿度 センサーを設置し、温度と相対湿度を測定した (写真3(a))。さらに、

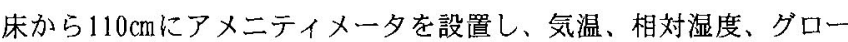
ブ温度、風速を测定した（写真3(b))。両装置とも1分間隔で計測し た。測定器の位置に関しては、測定対象室において高齢者自身が選 択した座席から1〜2m離れた位置に設置した。

高龄者の生理心理特性（視党障害や聴賞の加齢変化などの影響、 また、高齢者自身が申告内容を記入できない時の差恥心と自尊心 を考慮したケア）を考え、人間側要素に関するデー夕の収集は上 アリング調查により行った。高齢者の回答を的確に得るためには、 予め予備調査を行い、その結果を分析した上で、高齢者が理解し やすいアンケート用紙を作成した。なお、ヒアリング調查の際の 両者の座る位置について、面接時に良く使われる正面に対する座 位では被験者に緊張感を与えるため、本調査では正面に向かい合 つて座ることはせずに、高齢者に信頼感を与え、心理距離を短く するために横に並んで座るようにした。

室内の温熱環境に関する心理評価尺度としては 3 段階、 4 段階、 5 段階のカテゴリーを用意した。例えば、全身温冷感は 5 段階申 告生1(2:暑い、1: やや暑い、0：どちらでもない、-1：やや寒い、 -2 : 寒い)、温熱的快適感怡 4 段階申告 (快適、や快適、やや不快、 不快)とした。「足元が冷える感じ」と「空気の匂いを感じる」な どの質問については 3 段階評価（感じる、やや感じる、感じない） とした。なお、高跉者による回答の信頼性を高めるために長谷川
表 1 調查施設の概要

\begin{tabular}{|c|c|c|}
\hline & $\begin{array}{c}\text { 通所介護りnビ リテーション } \\
\left(\check{F}^{*} \text { 你 }\right)\end{array}$ & $\begin{array}{l}\text { 通所介護 } \\
\left(\dot{T}^{+} 1+\forall-匕^{*} Z\right)\end{array}$ \\
\hline 竣工年 & 平成 9 年 8 月 & 平成 5 年 4 月 \\
\hline 定員 & 40 人 & 55 人 \\
\hline 面樻 & $131.97 \mathrm{~m}^{2}$ & $165.96 \mathrm{~m}^{2}$ \\
\hline 生活相談買 & 4 人 & $2 \Lambda$ \\
\hline 看護師 & 4 人 & 2人 \\
\hline 医師 & 3 人 & 0 人 \\
\hline 介護職員 & 5 人 & 11 人 \\
\hline 構造・規模 & $\mathrm{RC}$ 造地上 1 階 & $\mathrm{RC}$ 造地上 1 階 \\
\hline 冷暖房方式 & Iアコン（天吊型と埋込型） & Iアコン（天吊型） \\
\hline 冷䐘房温度設定 & 職員 & 職員 \\
\hline
\end{tabular}

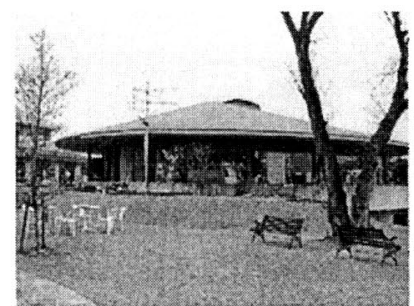

(a) $\vec{\top}$ 你

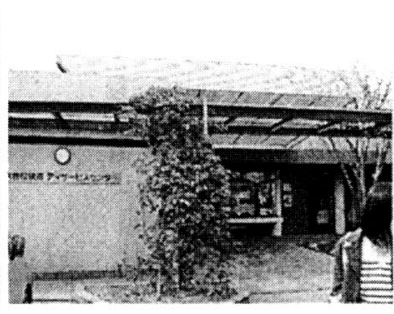

(b) $\overrightarrow{T^{*}}$ 仯-ビ
写真 1 調查施設の外観

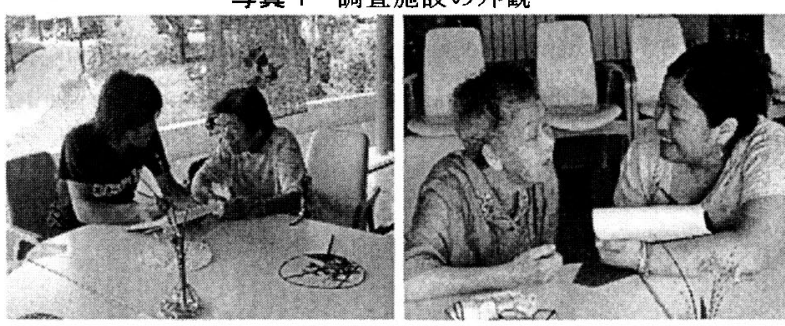

写真 2 とアリング調査時の様子

\begin{tabular}{|c|c|}
\hline 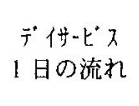 & $\begin{array}{l}9: 00 \text { 到着 } \Rightarrow \Rightarrow 10: 00 \text { 健康チエック } \Rightarrow \Rightarrow 11: 00 \text { レクリエーション } \\
\Rightarrow \Rightarrow 12: 00 \text { 昼食 } \Rightarrow \Rightarrow 13: 00 \text { 入浴 } \Rightarrow \Rightarrow 15: 00 \text { 自由時間（マッサー } \\
\text { ジ、リハビリ、散歩など） } \Rightarrow \Rightarrow 16: 00 \text { 帰宅 }\end{array}$ \\
\hline $\begin{array}{c}\vec{Y}^{*} \text { 你 } \\
1 \text { 日の流れ }\end{array}$ & $\begin{array}{l}9: 00 \text { 到着 } \rightarrow \rightarrow 10: 00 \text { 健康于エック、リハビリ } \Rightarrow \Rightarrow 11: 30 \text { 昼食 } \Rightarrow \\
\Rightarrow 12: 00 \text { 自由時間 } \Rightarrow \Rightarrow 13: 00 \text { レクリエーション、個人リハビリ、 } \\
\text { 作業療法 } \Rightarrow \Rightarrow 15: 00 \text { おやつ } \Rightarrow \Rightarrow 15: 30 \text { 㷌宅 }\end{array}$ \\
\hline
\end{tabular}

表 3 調查期間、天候及び調查対象者の基本情報

\begin{tabular}{|c|c|c|}
\hline \multirow{2}{*}{ 調查期間 } & 2005 年冬季調查 & 2005 年夏季調查 \\
\hline & 2 月 2,28 日, 3 月 $9,10,11$ 日 & 7 月 $14,15,16,19,21,22$ 日 \\
\hline 調查日天侯 & いずれも晴れ & いずれも晴れて \\
\hline $\begin{array}{l}\text { 調査期間 } \\
\text { 屋外気候 }\end{array}$ & $\begin{array}{l}\text { 温度 } 9.3^{\circ} \mathrm{C} \sim 19.3^{\circ} \mathrm{C} \\
\text { 平均外気温 } 15.7^{\circ} \mathrm{C}\end{array}$ & $\begin{array}{l}\text { 温度 } 23.6 \sim 32.8^{\circ} \mathrm{C} \\
\text { 平均外気温 } 30.5^{\circ} \mathrm{C}\end{array}$ \\
\hline サンプル数 & $\begin{array}{l}41 \text { 人 (延べ } 69 \text { 件 }) \\
\text { 男 } 12 \text { 人·女 } 31 \text { 人 }\end{array}$ & $\begin{array}{l}78 \text { 人(延べ } 156 \text { 件) } \\
\text { 男 } 17 \text { 人.女 } 61 \text { 人 }\end{array}$ \\
\hline 高齢者年龄 & $\begin{array}{ll}\text { 年齢構成 } & 63 \text { 葴 } 97 \text { 歳 } \\
\text { 平均年歯 } & \text { 男 } 79 \text { 歳·女 } 84 \text { 歳 }\end{array}$ & 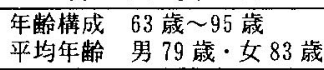 \\
\hline 高齡者着衣量 & $1.26 \mathrm{c} 10$ (平均値) & $0.54 \mathrm{cl} 0$ (平均值) \\
\hline 調查員着衣量 & $0.9 \mathrm{cl} 0$ (平均值) & $0.43 \mathrm{cl} 0$ (平均值) \\
\hline
\end{tabular}

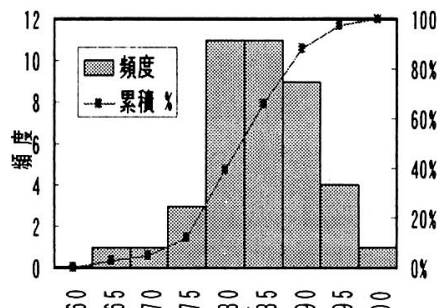

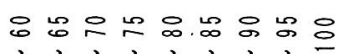

(a) 冬季

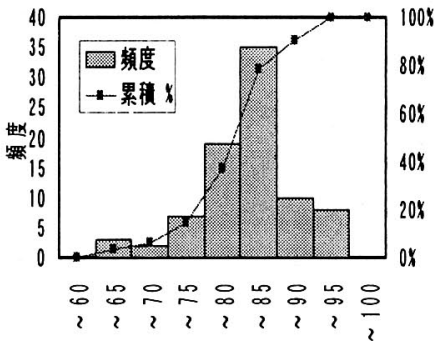

(b) 夏季

図 1 高齢者の年齢ヒストグラム 
式簡易知能評価スケールを用いて認知症の進行状態を調べた。な お、高齢者による回答の信頼性を高めるために長谷川式簡易知能 評価スケールを用いて認知症の進行状態を調べた。知能スケール の満点は 30 点であり、解析には調查員が測定した知能標準スケー ルの結果が冬季 15 点以上の高齢者(施設側の判断では認知症が無 いと認められた高齢者)、夏季は 20 点以上の高齢者のデータを使 用している。

\section{3 着衣量と活動量}

図 2 は高齢者と調查員の着衣量ヒストグラムである。冬季調查 では高齢者の着衣量は $0.6 \mathrm{cl}$ ０２.2c10 に分布し、表 2 で示した ように平均着衣量江 $1.26 \mathrm{c} 10$ である。調查員（若龄者）の平均着 衣量 $0.9 \mathrm{c} 10$ と比べると高齢者が厚着をしていることが分かる。一 方、夏季の調查では比較的厚めの下着を着用している高齢者も見 られ、着衣量は幅が広く $0.31 \mathrm{cl} 10 \sim 1.13 \mathrm{c} 10$ に分布し、平均着衣 量は $0.54 \mathrm{cl} 0$ である。調查員（若龄者）は平均 $0.43 \mathrm{c} 10$ であり、 高齢者より $0.11 \mathrm{cl} 10$ 小さい。高歯者の着衣量調節に関しては、飯 野らが特別盖護老人ホームに㧍いて調查し、高秢者では夏季、冬 季とも一般の人に比べて厚着をしていると報告した ${ }^{22}$ 。五十嵐ら は冬季における軽費老人ホームの室温と $\mathrm{cl} 0$ 值の関倸は認められ なかったと報告している ${ }^{13)}$ 。今回の調查から得られた着衣量に関 する結果も同様の傾向になった。

高齢者の活動量データについては資料が少なく、実験室内で椅 座安静時調查結果があるだけであり、談話時のデー夕は入手でき なかった。本論文は一般的な室内作業活動の代謝量値を使用し、 両季節とも高齢者 $1.0 \mathrm{met}$ (椅子座安静)、調查員 $1.2 \mathrm{met}$ (座業) を仮定した。

\section{3. 調查結果}

\section{1 室内温熱環境}

調查対象施設の冷暖房には埋込型と天吊型エアコンディショナ 一が使用されており、加湿器は使用していない。図 3 に冬季暖房 時（2005 年 2 月 25 日 3 月 11 日）と夏季冷房時（2005 年 7 月 14 日〜7月 22 日）の調查施設におけるヒアリング時間帯の室内（床 から $110 \mathrm{~cm}$ ）温湿度平均值を示す。なお、表 3 に示したように、 両季節ともいずれも調查日は晴れであった。冬季調查期間の外気 温度は $9.3^{\circ} \mathrm{C} \sim 19.3^{\circ} \mathrm{C}$ (平均 $15.7^{\circ} \mathrm{C}$ ) であり、夏季調查期間の外 気温度は $23.6^{\circ} \mathrm{C} \sim 32.8^{\circ} \mathrm{C}$ (平均 $30.9^{\circ} \mathrm{C}$ ) であった。冬季の場合、室 内の空気温度は $20.5^{\circ} \mathrm{C} \sim 24.8^{\circ} \mathrm{C}$ (放射温度は $20.8^{\circ} \mathrm{C} \sim 25.1^{\circ} \mathrm{C}$ )の 籁囲で変動している。高齢者に配慮した冬季の室温基準值は $23 \pm 2^{\circ} \mathrm{C}$ といわれており ${ }^{14)}$ 、調査施設の空気温度はいずれの調查日 もほぼ基準値を満たしている。一方、夏季室内の空気温度は $25.4^{\circ} \mathrm{C}$ $\sim 28.8^{\circ} \mathrm{C}$ (放射温は $25.5^{\circ} \mathrm{C} \sim 29.6^{\circ} \mathrm{C}$ )である。高齢者に配慮した夏 季の室温基準值 $25 \pm 2^{\circ} \mathrm{C}^{14)}$ に対し、調查施設の空気温度は午前中 には基準值内に納まっているが、午後はやや高い傾向があった。

相対湿度を見ると、冬季は $35 \%$ ～71\%の籁囲で変動した。一方、 夏季は $44 \%$ 71\%であり、冬季より若干高くなっている。このよ うに両季節の相対湿度は、ビル管理法の基準值 40\%〜 70\%をほぼ 満足した。冬季調查では午後は午前より高い傾向にあるが、高歯 者の入浴と昼食により室内の水蒸気量が增加することが原因と思 われる。また、夏季の場合、エアコンによる除湿のため午前と午

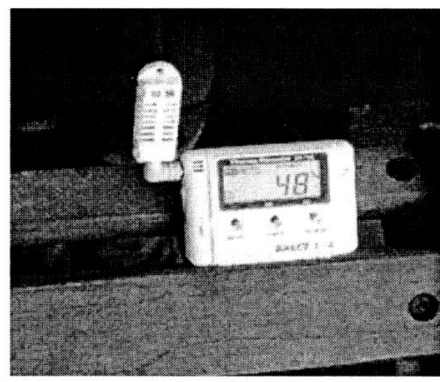

(a) 小型温度センサー

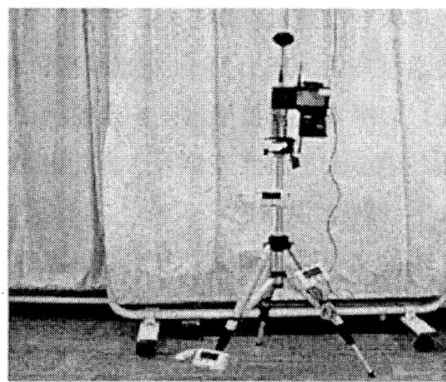

(b) アメニティメータ
写真 3 小型温度センサーとアメニティメータ

表 4 実測及びヒアリング調查項目

\begin{tabular}{|c|c|c|}
\hline \multicolumn{2}{|r|}{ 調查項目 } & 測定機材・調查内容 \\
\hline \multirow{2}{*}{$\begin{array}{l}\text { 物理 } \\
\text { 環境 } \\
\text { 要素 }\end{array}$} & PMV & $\begin{array}{l}\text { アメニティメータ (床上 } 110 \mathrm{~cm}) 、 \text { 温度、相刘湿度、 } \\
\text { ダロープ温度、気流速度 }\end{array}$ \\
\hline & 温度、相㸚湿度 & 小型温度センサー（床上 $10 \mathrm{~cm} 、 60 \mathrm{~cm} 、 150 \mathrm{~cm}$ ) \\
\hline \multirow{12}{*}{$\begin{array}{c}\text { 人間 } \\
\text { 䁚 } \\
\text { 要素 }\end{array}$} & 回答者属性 & 年齢、性別、体調、主観健康度 \\
\hline & 䛳知症の進行状態 & (ADS-R)長浴川式簡易知能評価スケール ${ }^{10)}$ \\
\hline & 体温 & MC-510 オムロン耳式体温計 \\
\hline & 着衣量 & 衣服単品 $\mathrm{Cl} 0$ 值を加算し男女別回帰式 (1) で計算 \\
\hline & 温冷感 & $\begin{array}{l}5 \text { 段階(暑い、やや暑い、どちらでもない、やや寒い, } \\
\text { 寒い) }\end{array}$ \\
\hline & 足元が泠える感じ & 3 归階(感じる、やや感じる、感じない) \\
\hline & 湿度感 & 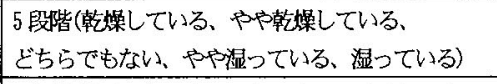 \\
\hline & 気流感 & $\begin{array}{l}4 \text { 段階(非常に気になる、気になる、やや気になる、 } \\
\text { 気にならない) }\end{array}$ \\
\hline & 快適感 & $\begin{array}{l}\text { 温熱䍗境に対し } 4 \text { 段階(快適、やや快適、やや不快、 } \\
\text { 不快) }\end{array}$ \\
\hline & 満足度 & $\begin{array}{l}\text { 温熱器境に対し } 4 \text { 段階（満足、やや満足、やや不满 } \\
\text { 不満) }\end{array}$ \\
\hline & 空気の污㣗、包い & 3 段階(感じる、やや感じる、感じない) \\
\hline & 施設について & 快適な温度、エアコンの使用有無 \\
\hline
\end{tabular}

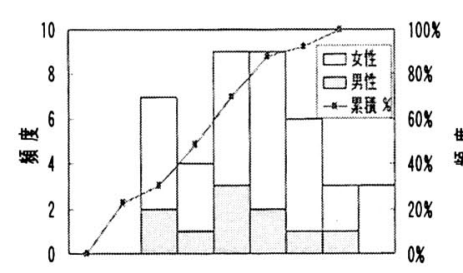

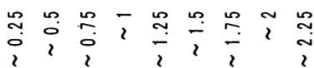

着衣 $[\mathrm{clo}]$

(a) 冬季高齢者

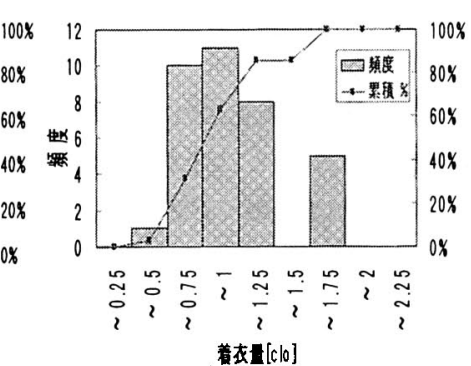

(b)冬季調查員 (若齢者)

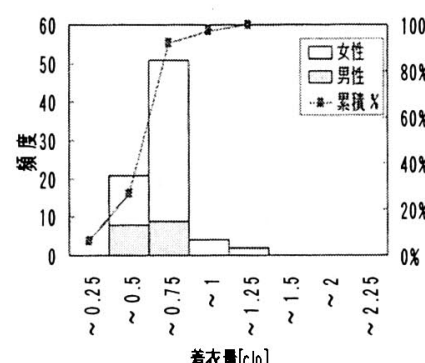

(c) 夏季高龄者

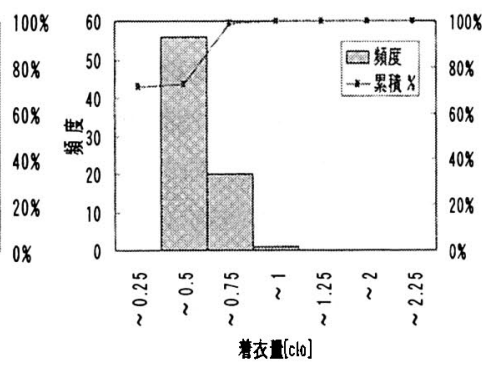

(d) 夏季調查員 (若此者)
図 2 着衣量のヒストグラム 
後に大きな差はなかった。また、表 5 には主な室内温熱環境 要素（室温、林上 $10 \mathrm{~cm}$ 空気温度、相対湿度、PMV、上下温度 差）の平均及び標準偏差を示す。この表よりデイケアにおけ る冬季の上下温度差が大きいことが分かる。

\subsection{PMV と温冷感}

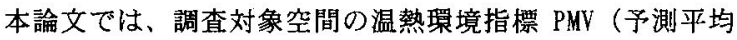
温冷感)を用いた。これはアメニティメータで測定した $4 つ$ の要素（気温、グローブ気温、気流速度、湿度）と 2.3 節で 述べた活動量の仮定值、高齢者之調査員が実際に着ているそ れぞれの着衣量をIS07730（国際標準化機構の規格）で規定 されているFANGER のPNV 予测式に代入して求めた。

図 4、図 5 は冬・夏両季節の PMV と温冷感申告の比較結果 である。また、右側の横棒図は申告者割合 (\%)及び申告件数 を示す。冬季調查において高齢者（図 4 (a)）に対するPMV 測 定值は-0.74〜1.52 と幅があるが、申告結果は「どちらでもな

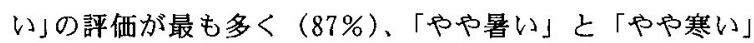

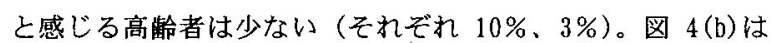
冬季調查員 (若齢者) の結果である。調查員に対する PMV 測 定值は $-0.72 \sim 0.83$ であり、申告結果を見ると、「暑い」 (22\%)、「队や暑い」(33\%)、「どちらでもない」(35\%)、 「やや寒い」(10\%) と大きなばらつきがあった。高秢者と 若齢者の温冷感申告に対し、コルモゴロフースミルノフの検 定（2 標本、以下 $\mathrm{k}-\mathrm{s}$ 検定と略称）を行った結果、両標本に は有意な差が認められた $\mathrm{p}(<0.05)$ 。なお、温冷感申告の差に は高齢者と若齢者の着衣量の差の影響が含まれるため、温冷 感申告とPMV との相関について検討を行った。まず、高齢者 において相関係数は 0.07 であり、無相関の検定の結果、こ の調查データからは有意な相関があるとはいえないという 結果となった（ $\mathrm{p}>0.05 ） 。 一$ 方、調查員の場合、正相関が認 められ、相関倸数は 0.31 である。なお、無相関の倹定によ り、母集団に有意な相関関係が認められる $(\mathrm{p}<0.05)$ 。以上 のように、高齢者と若齢者の温冷感申告には明らかな違いが 認められた。

一方、夏季の調査において高齢者（図 5(a)）に対するPMV 測定值は-0.73〜1.74 と幅があるが、申告では「どちらでもな

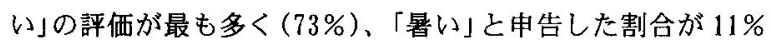
で、「やや暑い」(12\%) 及び「やや寒い」(4\%) と感じる高 齢者は少ない。調查員（図 5(b)）に対するPMV 測定値は-0.5 〜 1.92 であり、申告は「暑い」4\%、「やや暑い」 $65 \%$ 、「ど ちらでもない」25\%で、「やや寒い」は $6 \%$ であった。このよ うに夏季温椧感について、調査員が「暑い」「やや暑い」という申告 が多かったのに対し、高龄者のほとんどは「どちらでもない」が多 かった。冬季と同様に温冷感申告とPMV の相関係数の検定を行うと、 高齢者において相関係数は 0.03 であり、有意な相関があるとはいえ ないという結果となった $(\mathrm{p}>0.05)$ 。一方、調查員の場合、相関係数 は 0.20 であり、母集団に有意な相関関係が認められる（ $\mathrm{p}<0.05 ） 。$

\section{3 上下温度差と足元が冷える感じ}

図 6、図7に冬季と夏季における休上 $110 \mathrm{~cm}$ と $10 \mathrm{~cm}$ の空気温度差 と「足元が椧える感じ」の関係を示す。また、右側の横棒図は申告 者割合 $(\%)$ 及び申告件数である。冬季暖房時、IS07730（国際標準化
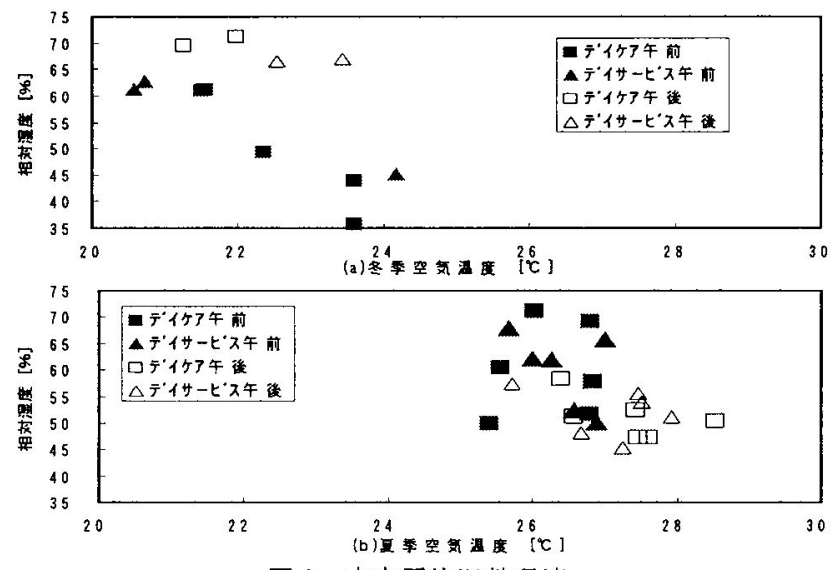

図 3 室内平均温熱環境

表 5 主な公内温熱環境要素の平均値及び標淮偏差

\begin{tabular}{|c|c|c|c|c|c|c|c|c|c|c|c|c|c|}
\hline \multirow{2}{*}{\multicolumn{2}{|c|}{ 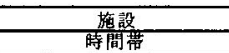 }} & \multicolumn{3}{|c|}{ 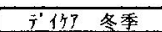 } & \multicolumn{3}{|c|}{ 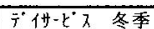 } & \multicolumn{3}{|c|}{ 于'你了基季 } & \multirow{2}{*}{\multicolumn{3}{|c|}{$\vec{y}^{*} 1+t^{\circ} \lambda$ 夏季 }} \\
\hline & & 年前 & 午後 & 全体 & 午前 & 4 & 全体 & 午前 & 千後 & 全体 & & & \\
\hline 室温 $(110 \mathrm{~cm})$ & 平均 & 22.6 & 23.9 & 23.3 & 22.7 & 22.4 & 22.6 & 26.4 & 27.2 & $\frac{5.8}{26.8}$ & 26.7 & 26.8 & 26.7 \\
\hline $\mathrm{C}$ & 根䇲何差 & 0.6 & 1.4 & 1.0 & 1.5 & 0.8 & 1.2 & 0.8 & 0.8 & 0.8 & 0.7 & $T .1$ & 0.9 \\
\hline 空気湓度 $(10 \mathrm{~mm})$ & 平均 & 19.3 & 21.4 & 20.3 & 20.4 & 22.4 & 21.4 & 26.1 & 27.7 & 26.9 & 26.2 & 27.3 & 26.8 \\
\hline c & 标策保差 & 1.5 & 0.4 & 0.9 & 1.2 & 1.6 & 1.4 & 0.9 & 1.1 & 1.0 & 1.0 & 1.2 & 1.1 \\
\hline 相対温度 $(10 \mathrm{~cm})$ & 平均 & 48.8 & 56.5 & 52.7 & 53.4 & 58.4 & 55.9 & 58.1 & 51.2 & 54.7 & 59.4 & 51.1 & 55.2 \\
\hline$\%$ & 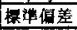 & 8.1 & 9.8 & 8.9 & 8.2 & 7.4 & 7.8 & 7.9 & 6.2 & 7.0 & 6.6 & 4.5 & 5.6 \\
\hline$P x y$ & 平均 & 0.2 & 0.5 & 0.3 & 0.2 & 0.5 & 0.4 & 0.2 & 0.5 & 0.3 & 0.4 & 0.5 & 0.5 \\
\hline & 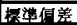 & 0.5 & 0.5 & 0.5 & 0.4 & 0.4 & 0.4 & 0.4 & 0.4 & 0.4 & 0.4 & 0.5 & 0.4 \\
\hline 上下温度差 & $\begin{array}{l}\text { 平均 } \\
\end{array}$ & 3.7 & 2.7 & 3.2 & 2.3 & $\frac{1.6}{1.6}$ & 1.9 & 0.4 & -0.4 & 0.0 & 0.4 & -0.4 & 0.0 \\
\hline$(110-10 \mathrm{~cm}) \times$ & 提準何差 & 1.5 & 0.8 & 1.1 & 1.0 & 1.1 & 1.1 & 0.8 & 1.2 & 1.0 & 0.8 & 1.2 & 1.0 \\
\hline
\end{tabular}

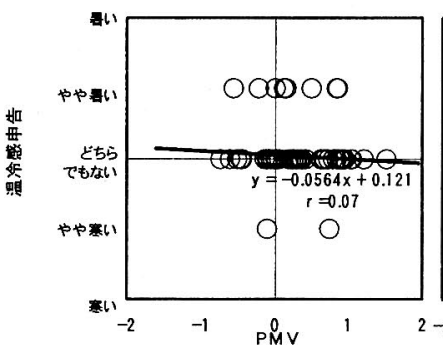

(a) 冬季高龄者

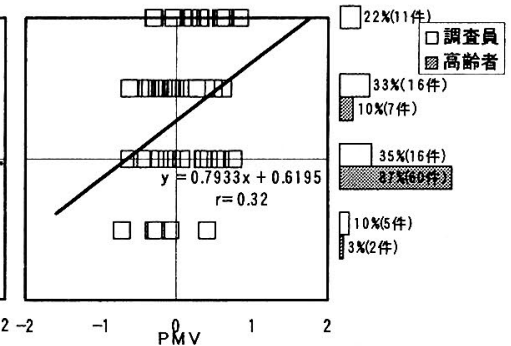

(b) 冬季調查員 (若龄者)

図 4 冬季. PMV と温冷感申告

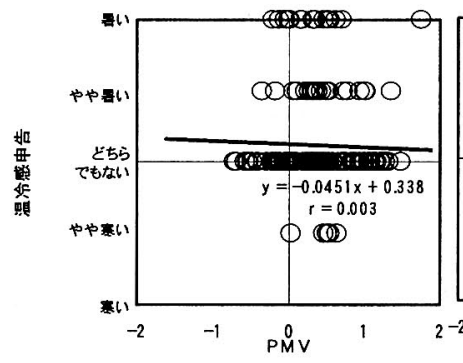

(a) 夏季高龄者

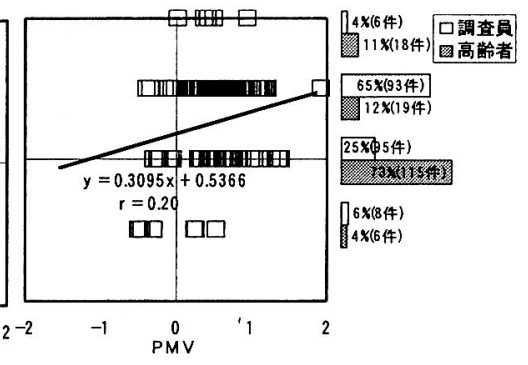

(b) 夏季調查員 (若龄者)

機構の規格）では「上下温度差」について $\pm 3^{\circ} \mathrm{C}$ 以内を推奖している が、表 5 に示したように冬季調査において調査対象施設特にデイケ アでは上下温度差が大きい。これは、前述したように、調查場所を 高秢者が選択する際、エアコンの近くに座る高齢者が多く、エアコ ンの吹出し口からの温風の影響で上下温度差が大きくなったと思わ れる。そのような条件の中で高龄者之若齢者の間には有意な差が認 められた。すなわち、高齢者の場合、上下温度差 $-0.2^{\circ} \mathrm{C} \sim 5.8^{\circ} \mathrm{C}$ に対 し、78\%の被験者は足元の冷えを「感じない」と申告し、「感じる」、 「やや感じる」と申告した被験者は $22 \%$ あった（図 6(a)）。冬季調 查員の場合、上下温度差 $-1.0^{\circ} \mathrm{C} \sim 5.2^{\circ} \mathrm{C}$ に対し、 $15 \%$ の調査員が「感 
じない」という申告であったが、85\%は「感じる」、「やや感 じる」と申告した（図 6(b))。このような上下温度差申告に対 し、 $\mathrm{k}-\mathrm{s}$ 検定により高齢者之調查員 (若齢者) の上下温度差 を検定した。その結果、高齢者は調查員 (若齢者) より上下 温度差感じないという申告が多いといえる（片側検定、 $\mathrm{p}\langle 0.05)$ 。以上のように、高齢者においては上下温度差感が 鈍いことを明らかにした。この結果について詳しく調べると、 冬季に下半身の着衣量が大きい高㱓者社 2 浊高齢者全体の $29 \%$ あった。言い換えれば、約 7 割の高龈者の下半身着衣 量は調查員とほぼ同程度である。図6で示したように、下半 身の着衣量に関わらず、高齢者の上下温度差申告は「感じな いが多かった。

一方、夏季の場合、高龄者（図 $7(\mathrm{a}))$ は $-0.9^{\circ} \mathrm{C} \sim 3.2^{\circ} \mathrm{C}$ の 上下温度差に対し、77\%が足元の冷えを「感じない」と申告し、 「感じる」「やや感じる」と申告した高龄者は少なかった（そ れぞれ 7\%、16\%)。調査員の申告（図 7(b)）では、上下温 度差が-1. $0^{\circ} \mathrm{C} \sim 3.4^{\circ} \mathrm{C}$ に対し、申告結果を見ると $68 \%$ の調查 員は「感じない」という申告であったが、6\%は「感じる」、26\% が「やや感じる」と申告した。夏季の高齢者と調查員 (若㱓者) の標本分布の異違を検定するため、 $\mathrm{k}-\mathrm{s}$ 検定を用いた。その 結果、夏季において、高齢者と調査員 (若龄者) の上下温度 差感には有意な差は認められなかった（ $\mathrm{p}>0.05 ）$ 。以上のよ うに冬季高齢者の場合、上下温度差が知覚されにくいことが 分かる。

\section{4 相対湿度と湿度感}

図 8、図 9 は冬・夏両季節の湿度感についての集計結果で ある。右側の横棒図に申告者割合 (\%)及び申告件数を示す。 冬季の低湿度環境と関連するインフルエンザの流行や皮膚 症は、施設にとって重要な問題であり、湿度は室内環境の良 否に対し不可欠な要素である。冬季 $34 \%$ 73\%の相対湿度に 対し、高齢者の場合「どちらでもない」が $84 \%$ と最も多く、 「やや乾燥している」は16\%である（図8(a))。しかし、同 じ相対湿度でも、調查員の場合は $18 \%$ 「乾燥している」と 感じ、55\%が「やや乾嬠している」と申告した（図 8(b))。調 查員と高䑪者の湿度感に対し、 $\mathrm{k}-\mathrm{s}$ 検定を行った。その結果、 調查員は高齢者より乾燥という申告が多いといえる（片側検 定、 $\mathrm{p}(0.05)$ 。

一方、夏季の場合は $44 \%$ 71\%の相対湿度に対し、高齢者 は中立申告「どちらでもない」が $75 \%$ と最も多く、「やや乾 燥している」は13\%、「乾燥している」が8\%、「やや湿って いる」が4\%であった（図 9(a))。同じ相对湿度でも、調查員の場合 は $6 \%$ 「やや乾燥している」、72\%が「どちらでもない」と申告し たが、「やや湿っている」という申告が $21 \%$ であった（図 $9(\mathrm{~b}))$ 。夏 季について、k-s 検定 (2 標本) を行った結果、高齢者は若龄者より 乾燥という申告が多いこといえる(片側検定、 $p<0.05)$ 。冬季と同様、

高齢者と調查員の申告には違いが見られた。

\section{5 室内温熱環境に対する満足感及び快適感}

図 10、図 11 に満足感と不満足率 PPD の関係を示す。このPPD は前 述したPMV 值を以下の計算式に代入して求めた。 $\mathrm{PPD}=100-95 \exp [-(0.03353 \mathrm{PMV} 4+0.2179 \mathrm{PMV})]$

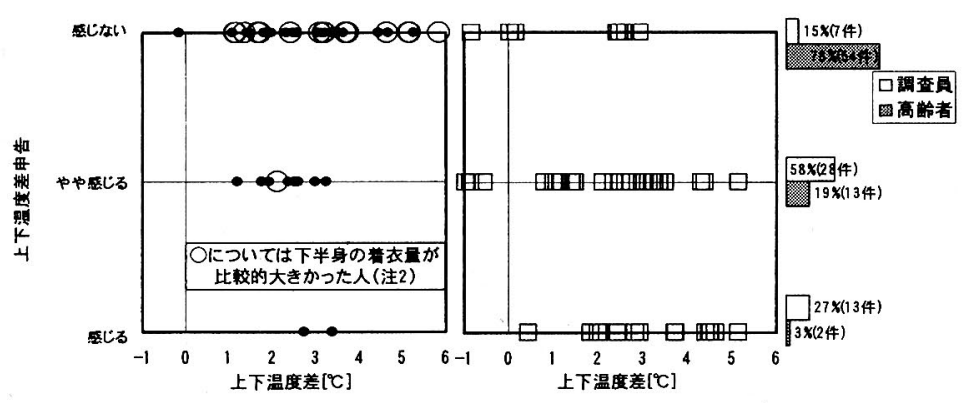

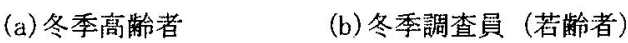

图 6 冬季・上下温度差と足元が冷える感じ

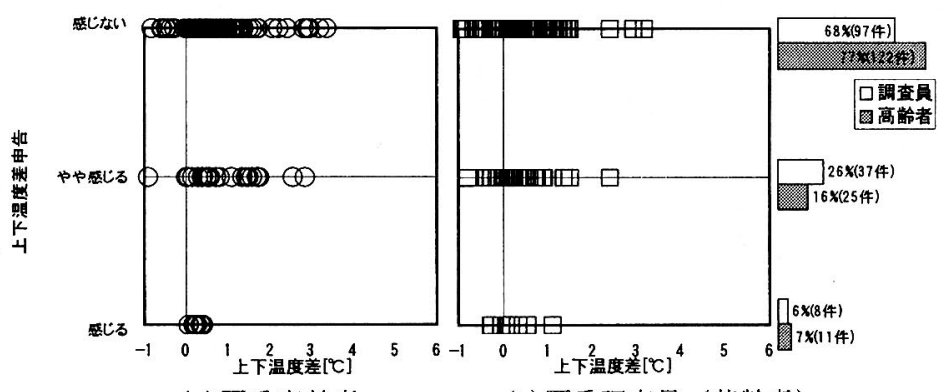

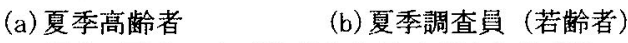

图 7 夏季・上下温度差と足元が泠える感じ

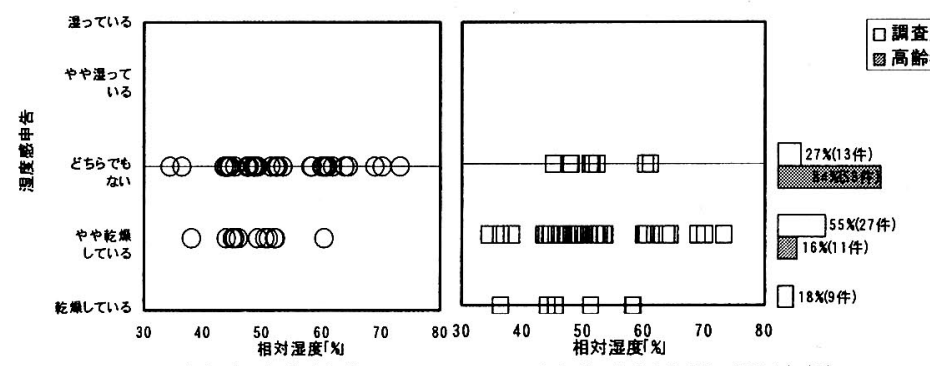

$\begin{array}{ll}\text { (a) 冬季高齢者 } & \text { (b) 冬季調查員 (若㱓者) }\end{array}$

図 8 冬季・相対湿度と湿度感申告

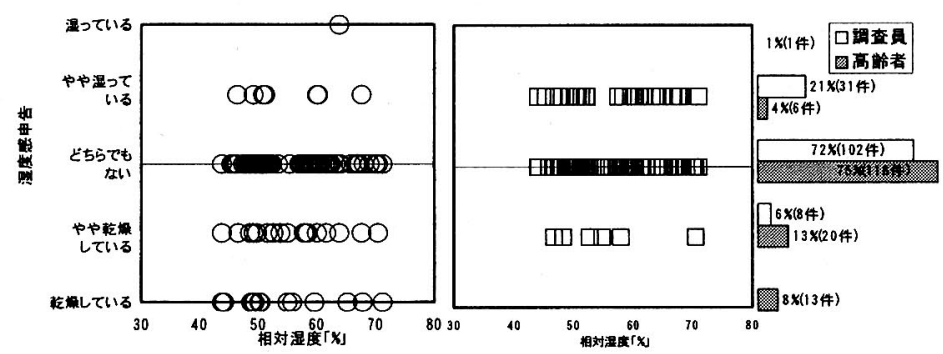

(a) 夏季高粭者 $\quad$ (b) 夏季調查員 (若齢者)

図 9 夏季・相対湿度と湿度感申告

当然のことではあるが、物理環境及び着衣量ならびに活動量の違 いによって、不満足率 PPD 法ばらつくが、特に高龄者に対する条件 で算定した PPD のばらつきが大きくなる。これは高齢者の着衣量の 影響と推測される。右側の横棒図は满足感申告における高龄者と調 查員の各選択肢に対する申告者割合 (\%)及び申告件数である。高秢 者の場合、冬季のPPDにおいて $10 \%$ を超える割合が約 5 割 (PPD の幅 は $5 \%$ 25\%)であるにも関わらず、ほぼ全員が「渵足」側に申告し た。調查員の場合、PPD $10 \%$ を超える割合が約 4 割(PPD の幅は $5 \%$ $27 \%$ )であり、满足感申告にはばらつきがあった。一方、夏季 (図 11) において、高齢者の場合、PPD の幅が $5 \%$ 73\%であるが、 $85 \%$ の高 
柃者が「满足」側に申告した。調查員ではPPD5\%〜 44\%に対し、 約半数が「不満」を感じた。調查員と高歯者の満足感に対し、 $\mathrm{k}-\mathrm{s}$ 検定を行った。その結果、高秢者は調査員より満足という 申告が多いといえる（片側検定、 $\mathrm{p}<0.05)$ 。このように高龄者と 調查員の間には温熱環境に対する満足感の違いが見られた。

暑さ寒さに対する快適感の申告結果を図 12、図 13 に示す。 冬季において室温が $20^{\circ} \mathrm{C} \sim 25^{\circ} \mathrm{C}$ に変化しても、69 件の高齢者の 回答のうち 68 件が「快適」「やや快適」と申告した。一方、調 查員の場合、「不快」 12 件、「やや不快」 16 件、「やや快適」 16 件、「快適」5件であった。調查員の快適感申告は满足感申告結 果之同様に申告の幅が広くなっている。一方、夏季では、 $89 \%$ の高齢者が「快適」「やや快適」と申告し、47\%の調査員が「不 快」「やや不快」と申告した。このような快適感申告に対し、k-s 検定を行った。その結果、高齢者は調查員（若齢者）よりが快 適という申告が多いといえる（片側検定、p〈0.05)。以上のよう に高跉者の快適感に対する評価が加踰により鈍化していると考 えられる。

熱的快適性を評価するためには、局部的な温熱感覚を考慮す ることも重要である。そこで人体の局部的な温冾感（足元と頭 の温度差）に着目し、その局部温冷感に基づいて、熱的快適性 を評価する。図 14 に上下温度差と快適感の関係を示す。夏季で は上下温度差が小さいので、この部分の解析を省略して、温度 差が大きい冬季において温度差と快適感の関係を分析すること にした。上半身（休上 $110 \mathrm{~cm}$ ） と下半身（佅上 $10 \mathrm{~cm}$ ）の室内空 気温度差が大きくなっても、高龄者の申告のほとんどが快適側 にあった。

一方、調查員の回答を見ると「快適」から「不快」まで幅が 広い申告をしているのが分かる。調查員は足元が冷える感じ、 頭が熱い感じのような、局部的な暑い寒い感覚などによる快・ 不快感の存在や、空気の垂直温度分布や放射の不均一性による 不均一熱環境が人体局部の温冷感を生じさせ、その局部的な暑 さ寒さの存在が、熱的快適性に影響する要因であると考えられ る。しかし、高齢者の場合、3.2節で述べた温冷感（図 4 、図 5 参照）と 3.3 節で述べた足元が冷える感じ（図6、図 7 参照） の結果を見ると、「どちらでもない」のような中立回答が多いた め、室内温度差を感じにくく、[熱的に快適]と申告したと思わ れる。

\section{4. まとめ}

本研究では北九州市近郊にある通所型福祉施設を対象に高柃 者の心理要素と温熱環境を調查し、若齢者（調查員）と比較検 討した。得られた結果は以下の通りである。

1）冬季の温冷感において、高秢者に対するPMV 測定值は-0.74 〜 1.52 と幅があるにも関わらず、申告では「どちらでもない」の 評価が最も多かった。一方、調查員の場合 PMV 測定値 $-0.72 \sim$ 0.83 に対して、申告結果には大きなばらつきが見られた。この ように両者の申告には有意な差が認められた（ $\mathrm{k}-\mathrm{s}$ 検定、 p $<0.05)$ 。夏季の温冷感において、高齢者に対するPMV 測定值は $-0.73 \sim 1.74$ 、調査員は-0.5〜1.92であるが、調查員において「暑い」 「やや暑い」という申告が多かったのに対し、高齢者の約 7 割は中

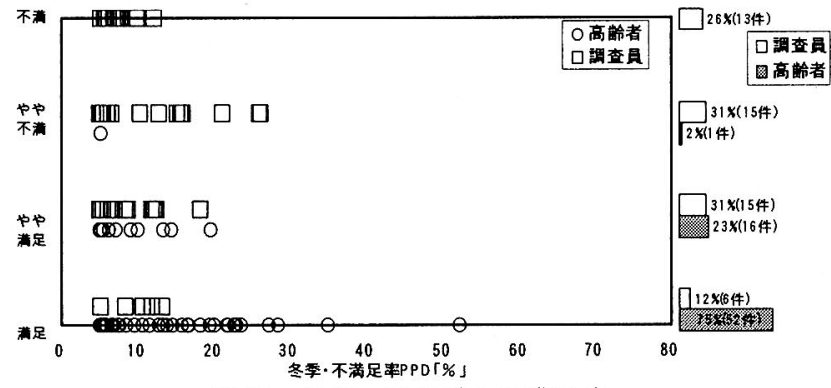

図 10 冬季・満足感と不満足率

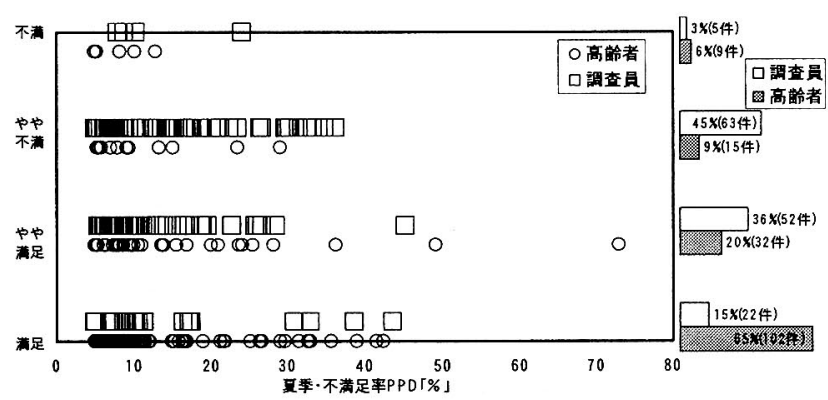

図 11 夏季・満足感と不満足

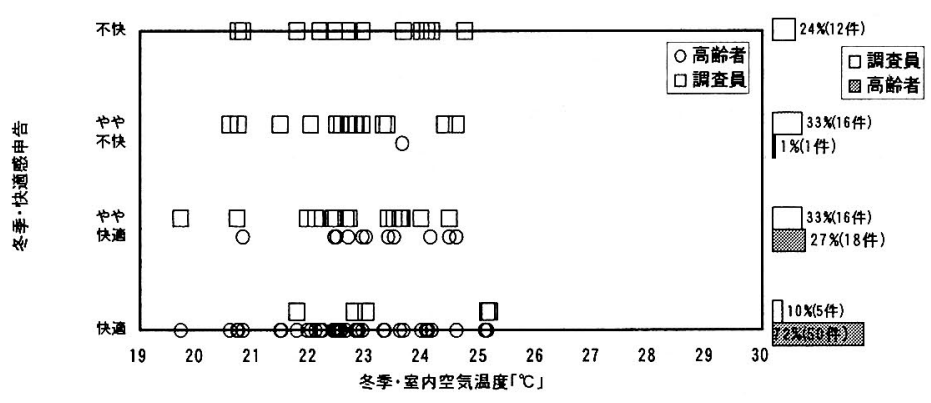

図 12 冬李・室内空気温度と快適感
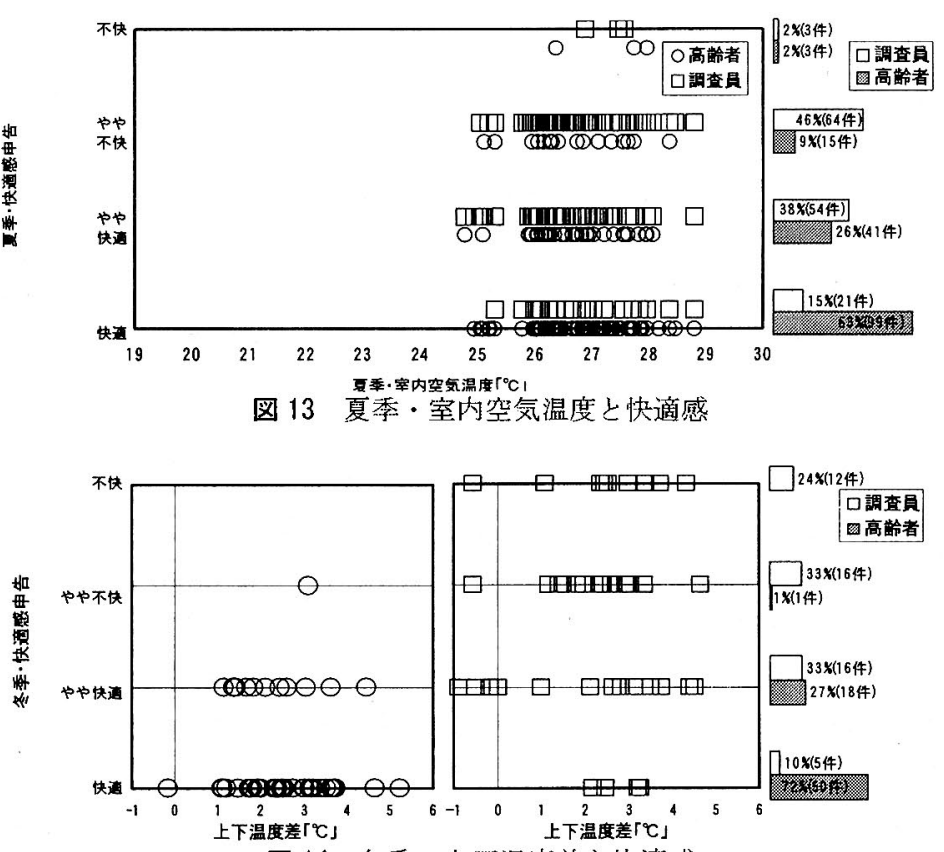

図 14 冬季・上下温度差々快適感

立申告「どちらでもない」であった。また、PMV と温冷感申告に関し、 若路者には有意な相関関係が認められるものの（p<0.05）、高齢者に 
おいては相関があるとはいえないという結果になった（ $\mathrm{p}>0.05 ） 。$ 2) 冬季の上下温度差感については、高跉者の場合上下温度差 $-0.2^{\circ} \mathrm{C}$ $\sim 5.8^{\circ} \mathrm{C}$ に対し、約 8 割が足元の冷えを「感じないよ申告した。調査 員の場合 $-1.0^{\circ} \mathrm{C} \sim 5.2^{\circ} \mathrm{C}$ の上下温度差に対し、8 割以上は「感じる」 と申告した。 $\mathrm{k}-\mathrm{s}$ 検定からも、高齢者の場合は上下温度差が知覚され にくいことが分かった（片側検定、 $\mathrm{p}<0.05 ） 。$

3）湿度感についても、温冷感及び上下温度差感のように高龄者と若 齢者（調査員）の申告に差が認められた。冬・夏両季節とも相対湿 度はほほ $40 \%$ 70\%の範囲にあったが、冬季は調查員が乾燥感を知 覚しているのに対し、高跲者は「どちらでもない」との申告が大半 を占めた。一方、夏季は調查員が乾燥を感じないのに対し、高齢者 は $21 \%$ \%乾燥を感じた。

4）調查員の約半数が不満足側の申告を行った温熱摼境において、高 齢者は冬季 $99 \%$ 、夏季 $85 \%$ が満足側の申告を行った。快適感につい ても同様な傾向が見られ、高歯者の満足感と快適感に対する評価が 加歯により鈍化していると考えられる。また、上下温度差による不 快感も認められない。

以上のように、日常生活空間での温熱環境調査とヒアリング調査 により、高齢者と若齢者の温冷感及び快適感には明確な差異が認め られた。加秢による温冷感の鈍化に配慮した室内熱環境の形成及び 冷暖房システムの工夫が必要であろう。

\section{参考文献}

1）入来正躬, 浅木恭: 高秢者の体温調節 バイオメカニズム学会誌 Vol.16 N0. 1 pp. 31-37, 1992

2) 内田幸子, 田村照子, 小田一之, 岩崎房子: 高齢女子における冷・温覚闗值の 変化 日本生理人類学会誌 HES26 in Nara, 6-7 Dec pp. 33-36 2002

3) 都築和代 : 冬期における高龄者の温冷感と体温調節反応 日本建筑学学術 講演梗概集 (北陸) $\quad$ D-2 $\quad$ pp. 395-396，2002.8

4）川島美勝, 佐藤篤史, 三沢高志, 後藤滋, 吉田 桑: 高齢者の体温調節と住宅 熱環境に関する研究 その 4 高龄者と青年の体温調節の比較実駼 日本 建築学会大会学術講演梗概集（東北） D-2 pp. 169-170，1991.9

5）衣笠奈々恵, 久保博子, 佐々尚美, 磯田憲生: 夏季における高齢者の至適温熱 罳境に関する実駼的研究 日本建筑学学術講演梗概集(近畿) D-2 pp. $483-484,2005.9$

6) 久保博子, 佐々尚美, 磯田憲生, 梁瀬度子 : 温熱的快適性の個人差に関する実 験的研究第 8 報 冬期における高齵者の選択気温 日本建築学会学術講演 梗概集（中国）D-2 pp. 349-350，1999.9

7) Fanger, P. 0: Thermal comfort, Mcgraw-Hill Book Company, New York, pp. $75-86,1970$

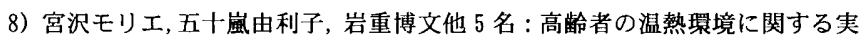
態調査（第1 報-第 3 報）日本家政学会誌 Vol.46 No. 5 pp. 447-454, No.5 pp. 455-464, No. 6 pp. 587-596, 1995

9) 依田浩敏, 福田展㴡: 北九州市内の高齡者施設における冷房時アンケート調 查 空気調和・衛生工学会 九州支部研究報告 第 11 号 pp. 1-6 2004.5

10）松原達哉編：心理テスト法入門 基樥知識と技法習得のために 日本文化 科学社 pp. 95-99, 2006.4

11) 空気調和・衛生工学会編 : 快適な温熱瑟境のメカニズム 豊かな生活空間 をめざして 空気調和・衛生工学会 2006.3

12）飯野由香利, 飯野秋城, 内山剛志: 特別盖護老人ホームと老人保健施設の居
室における入所者の居住域の温熱罢境 日本建築学会技術報告集 第 16 号 pp. 197-202, 2002.12

13）五十嵐由利子他: 高齢者居住施設の温熱䱜境について その 5 新潟県の軽 費老人ホームについての事例調查 日本建築学会大会学術講演梗概集 (北 海道) D-2 pp. 433-434, 1995.8

14）日本建築学会編：高齢者のための建築瑟境 彰国社 pp. $58 ， 1994$

注

注 1）本研究の予備調查において、温冷感に対しては非常に暑い（+3）から非 常に寒い（-3）に対応する7段階の心理申告を行ったが、冷暖房を使用し ている本施設では「非常に暑い」「非常に寒い」という申告は出なかった。 そのため、本調査においては、実質的回答範围内 5 段階を絞った。なお、 本研究では暑いは warm、やや暑いは slightly warmに対応している。ま た、寒いはc0ol、やや寒いはslight coolに対応している。

注 2) 冬季下半身の着衣状況については大部分の高龄者がズボンであり、女性 3 人が長いスカートと厚いストッキングを着用している。足元着用状況は スリッパではなく、施設用上履きシューズを着用していた。そのうち、17 人の高齢者は厚い靴下あるいは 2 枚の靴下を着用した。本論文では、厚手 の靴下或は靴下 2 枚、ズボン下 2 枚、ひざ掛けなどを身に付けている高秢 者を下半身の着衣量が大きい高齡者と見なした。

(2007年 4 月10日原稿受理，2007年10月16日採用決定) 